\title{
Expresionismo y revolución: el abismo de la realidad
}

\section{Expressionism and revolution: the abism of the reality}

\section{Expressionismo e revolução: o abismo da realidade}

\section{Blanca Muñoz}

Universidad Carlos III de Madrid, Madri, Espanha

\begin{abstract}
RESUMEN
En este estudio se plantea el paso de la conciencia expresionista a la conciencia crítica; es decir, la evolución del Expresionismo artístico hacia la creación de la Teoría Crítica sociológica en la Alemania de la República de Weimar. De este modo, se repasan los procesos sociales y culturales que dieron lugar a un tipo de Arte en el que se reflejaban las profundas y dramáticas contradicciones de las primeras décadas del siglo XX, subrayándose por tanto como la Escuela de Frankfurt en su primera Generación (Adorno, Horkheimer, Benjamín) significó el punto de inflexión fundamental para analizar y entender filosófica y sociológicamente estas complejas y profundas contradicciones colectivas, así como sus consecuencias históricas posteriores.

Palabras clave: Conciencia crítica, Teoría Crítica, Contradicciones, Escuela de Frankfurt, Primera generación de la Teoría Crítica.
\end{abstract}

\begin{abstract}
This study emerges from the expressionist consciousness about the critical consciousness; in other words, the evolution of the artistic expresionism toward the creation of the critical Theory in the Germany of the Republic of Weimar. In this way, the social and cultural processes that gave place to a type of Art in which there were reflected the deep and dramatic contradictions of the first decades of the XXth century are revised, being underlined, therefore, that the School of Frankfurt in his First Generation (Adorno, Horkheimer, Benjamin) is the point of fundamental inflection to analyse and to understand philosophical and sociologically these complex and deep collective contradictions, as well as its subsequent and later historical consequences.
\end{abstract}

Keywords: Critical conscience, Critical Theory, Contradictions, School of Frankfurt, the First generation of Critical Theory.

\section{RESUMO}

Neste estudo expõe o a passagem da consciência expressionista para consciência crítica; isto é, a evolução do Expressionismo artístico até a criação da Teoria Crítica sociológica na Alemanha na República de Weimar. O texto faz uma revisão dos processos sociais e culturais que deram lugar a um tipo de Arte na qual se reflete as profundas e dramáticas contradições das primeiras décadas do século $X X$, destacando-se como a Escola de Frankfurt, em sua primeira Geração (Adorno, Horkheimer, Bejamin), significou o ponto de inflexão fundamental para analisar e endender filosófica e sociologicamente estas complexas e profundas contradições coletivas, assim como suas consequências históricas posteriores.

Palavras-chave: Consciência crítica, Teoria Crítica, Contradições, Escola de Frankfurt, Primeira geração da Teoria Crítica. 


\section{I ntroducción}

El suicidio de Ernst Toller en 1939 en los Estados Unidos clausura y cierra los ideales de llegar a construir una sociedad humanizada. Toller perteneció a una generación de supervivientes. Una juventud que envejeció y murió prematuramente en las trincheras de la Primera Guerra Mundial. Para esta generación, angustia y rebeldía estuvieron unidas. Angustia ante la irracionalidad de la guerra, rebeldía ante la opresión de una sociedad en la que la obediencia y la subordinación habían convertido en un cuartel los escenarios sociales. Todo quedó militarizado en una Alemania que en los comienzos del siglo XX se adentraba poco a poco en los horrores de la Segunda Guerra. Terrores que se preludiaban ya en el Volkgeits de la Literatura que cierra el siglo XIX con el movimiento de la "joven Alemania" y el final de los ideales del Clasicismo y el Romanticismo de Schiller y Goethe ${ }^{1}$ (FRIEDERICH, 1973).

Es paradójica la evolución filosófica y literaria alemana desde la "Aufklarung" del siglo XVIII hasta el Expresionismo del XX. De los ideales ilustrados de Lessing y de la confianza serena en la racionalidad de Kant se pasa a la exaltación de los instintos de Jünger y a la irracionalidad de Spengler. Será, por tanto, Hölderlin quien compendie el símbolo máximo de una sociedad en perpetua contradicción entre lucidez y locura, entre clarividencia y enajenación. La tormenta y el ímpetu ("Sturm und Drang"), el sosiego y la calma explican que a comienzos del siglo XX se sinteticen, como los hilos multicolores de un gigantesco tapiz, los más dispares y contradictorios elementos creativos. Así, el Neo-romanticismo, el Simbolismo, las corrientes literarias Cósmicas y el Impresionismo serán asumidos y, a la vez, reemplazados por un movimiento que como el Expresionismo profetiza y anuncia el abismal malestar de un tiempo de entreguerras y exaltación militarista. El Expresionismo, entonces, resulta inseparable de un marco político que a lo largo de la República de Weimar (1919-1933) está en vísperas del Nazismo y de la Alemania vencida y dividida de la postguerra (KLEIN, 1970). Es tan inseparable el desarrollo paralelo de Arte y Política desde 1910, - fecha en la que puede considerarse el origen del Expresionismo -, hasta 1933, - momento en el que logra el poder el Nacionalsocialismo, que sería imposible entender el significado ideológico fundamental de las obras de Georg Kaiser, Alfred Döblin, Ferdinand Bruckner, o el mismo Ernst Toller, sin esta estrechísima relación entre creación y estado económico, social y cultural. De este modo, el Expresionismo refleja esa situación de violencia y ansiedad colectivas. Pero, especialmente, es el espejo en el que experimentamos la quiebra de la conciencia europea y los sentimientos angustiados de sus más conscientes intelectuales y creadores. 
La crisis de la cultura europea de entreguerras acentúa la desconfianza en la coherencia de una sociedad acechada por la locura colectiva. "EI grito" de Eduard Munch plasma la inquietud metafísica ante una realidad cada vez menos comprensible y dominada por "un ciego destino". La tensión caracteriza la interpretación expresionista de lo real. Interpretación que es, al mismo tiempo, un radical desafío a la sociedad burguesa y sus convenciones. Por ello, la deformación expresará los estados anímicos del artista en cuanto "traductor" de la conciencia colectiva de la época.

El creador, por tanto, cobra un papel nuevo y diferente en la relación entre la obra creada y sus contempladores. Hasta el Expresionismo, el autor establece un universo en el que personajes y temas reproducen un sentido de lo exterior objetivado por la propia subjetividad creadora. Sin embargo, en la creación expresionista lo exterior es evocado como objetividad interiorizada. Es decir, la realidad social deviene en estado de ánimo. Sujeto y objeto coinciden y se hacen inseparables. Es el retrato de la conciencia la visión expresionista del mundo. Así será como se puede explicar el hecho de que haya sido el cine en gran medida el arte de artes en el Expresionismo. Cine y conciencia, mediados por el poder del subconsciente, están inherentemente unidos ${ }^{2}$ (KRACAUER, 1985). Y en esta unificación, los estados de ánimo se vuelven símbolos y los símbolos representaciones deformadas de una realidad alienada desde los sentidos de la dominación creados en las conciencias por la irracionalidad de unos poderes que convierten en irreal la existencia objetiva y transforman en ilógico lo razonable y explicable. En estas condiciones, deformación, conciencia y poder son los tres ejes a partir de los cuales comprender la reacción frente a un realismo ingenuo y sencillo.

En consecuencia, las deformaciones de la conciencia hechas por el poder y su dominación social son, en último término, el origen y destino de la creación expresionista. En este sentido, el derrumbe de la racionalidad colectiva es la grieta que el poder económico esclavizador ha abierto en el Siglo XX.

El Siglo XX, entonces, en cuanto Siglo de las Masas es la época del descubrimiento de la vida subconsciente. El hallazgo del Subconsciente fue la consecuencia de la complejidad que iba desarrollando la vida psíquica de los individuos. Abandonados a su suerte histórica, tras la dramática convicción de la "muerte de Dios" nietzscheana, los supervivientes de la Primera Guerra Mundial vagaron por los restos de unas sociedades en ruina a modo de espectros de Strindberg. Ese vagar sin rumbo semejará el abismo de vidas y sociedades en los recovecos de las imágenes del cine de Murnau. Cine y existencia se convierten en los ejes del nuevo Arte del Subconsciente Colectivo: el Expresionismo alemán.

Frente al Surrealismo, en cuanto Arte y Estética del Subconsciente Individual, con el Expresionismo las Masas "reciben" y expresan su vida 
inconsciente, pero ahora como urbana y anómica; mas, también, como búsqueda de cambios revolucionarios. Franz Wedekind y Ernst Toller serán los dos polos de un teatro que expresa los sentimientos y subjetividades de los dominados $y$, sobre todo, de quienes sobrevivieron en el primer conflicto bélico mundial del Siglo XX, pero que, a la vez, perdieron no ya la existencia cuanto la conciencia del bien y del mal, de lo social y de lo individual. El nuevo nihilismo postbélico sólo dejará dos alternativas: el asesinato o la rebelión. Los personajes de Wedekind (Lulú, Wozzeck) morirán trágicamente en el caos colectivo, los protagonistas de Toller, al contrario, se rebelarán frente a un destino inexorable que les oprime y corrompe. Será el Expresionismo del Subconsciente Social el que reaparecerá en la Historia y en la Literatura del Siglo XX. Y con esta aparición, los héroes mitológicos del wagnerianismo germano se verán sustituidos por el hombre común y anónimo, por ese "último hombre" que como en la película de Murnau es el temible presagio de que "la jaula de hierro" weberiana se ha transmutado en el psiquiátrico cruel y despiadado de Caligari.

Por ello, la representación de la irracionalidad del poder es una de las constantes temáticas del simbolismo expresionista. Desde Caligari hasta Mabuse o Nosferatu se proyecta la demencia como característica y referencia ineludible de una sociedad en la que "los nuevos ciudadanos", como en "El vampiro de Düsserdolf" de Lang, han interiorizado la locura que asesina a los débiles y la alienación que justifica esos asesinatos. Pero a la vez que el Expresionismo enseña la corrupción de una burguesía que aupará al Nazismo al poder, tambien nos señalará en su teatro cómo es posible salir de las sombras que nublan y oscurecen la Historia. Ernst Toller, tanto en su vida como en su obra, dará coherencia a aquella frase de Adorno según la cual: lo que es, no puede ser posible (ADORNO, 1975, p. 101-139).

\section{Del romanticismo al expresionismo: las fracturas de la conciencia social}

Alemania revela el espíritu contradictorio de la cultura europea. La tardía unificación política, sin embargo, no niveló las desigualdades sociales. Al contrario, las contradicciones históricas fueron el sustrato sobre el que se asentó la República de Weimar, y con ella se cerraron, pero a la vez se abrieron, nuevas confrontaciones y conflictos. Será, precisamente, en la creación literaria en donde mejor se exprese ese estado de conciencia general.

Remontándonos un siglo antes de la constitución de la República de Weimar, el movimiento de la "Joven Alemania" (Junges Deutschland) comienza una época literaria nueva al romper con los principios estéticos del Romanticismo. No obstante, el espíritu romántico, de una manera latente, pervivirá en la cosmovisión germana como parte esencial de su comprensión de la realidad. Ahora bien, ese espíritu romántico estará siempre caracterizado por "una doble alma": Fausto y 
Mefistófeles. Los dos personajes de Goethe definen la dualidad del mundo: el sabio y el demonio, la bondad y la maldad, la razón y la locura, la energía y la dominación. Entre dos extremos se trazan los límites de la conciencia y del mundo. Voluntad y representación, determinará Schopenhauer, son los principios y el origen de la existencia. La filosofía de Schopenhauer refleja en gran medida el estado anímico de una sociedad fragmentada entre una voluntad ciega que condiciona la existencia, y unas representación que se viven como ensoñaciones ajenas al propio individuo. Esta situación enajenada será el sustrato de una realidad en la que lo irracional se torna una experiencia social y política colectiva. De este modo, la evolución literaria y filosófica alemanas resultan los aspectos más objetivos para comprender el paso de la racionalidad a irracionalidad, y del idealismo al pesimismo y al nihilismo radical. De Goethe a Nietzsche hay un trayecto en el que se han hecho añicos los sueños hegelianos de un mundo en el que razón e historia coinciden. El crimen, la enfermedad y la guerra, para Schopenhauer, eran la única realidad existente. Schopenhauer, enemigo declarado de Hegel, expresa lo que generaciones posteriores van a sufrir como manifestación de "esa alucinada voluntad" que rije los destinos humanos. La esencia del mundo, como afirmará el filósofo antihegeliano (SCHOPENHAUER, 1942), no es más que un fugaz momento en el que el dolor cesa.

La derrota del pueblo alemán tras la Primera Guerra Mundial es el paisaje en el que cualquier recuerdo del Romanticismo literario o del Idealismo filosófico resulta una mueca hiriente. Mefistófeles sube sobre los hombros de Fausto como un odioso fardo del que es imposible desprenderse. El esplendor de un tiempo mefistofélico presagia el advenimiento del Nazismo. Será la República de Weimar (RAMOS OLIVEIRA, 1964) el advenimiento de los prestigitadores. Políticos que en apariencia ocultan el desastre bélico, intachables padres de familia habitantes asiduos de burdeles, hábiles empresarios expertos en tejemanejes, ciudadanos abocados al engaño como supervivencia, héroes de guerra mendigando como histriones de una comedia en la que todos han perdido su dignidad y coherencia. Todos ellos "decoran" el colosal mural de la metrópolis dibujada por Grosz. Ya no son hombres sino caricaturas. Los bocetos han cobrado vida y embadurnan su conciencia con el oportunismo de la supervivencia. $Y$ en esta crisis de civilización únicamente podrá surgir el Expresionismo.

Es paradójico el breve espacio de tiempo en el que se desarrolla el movimiento expresionista alemán. Entre 1910 y 1920 se abre, y se cierra, el momento de apogeo estético e intelectual del Expresionismo (RICHARD, 1979). Sin embargo, la cosmovisión expresionista se fue forjando espiritualmente durante el contradictorio siglo XIX. Kierkegaard y Nietzsche, Strindberg y Dostoievski, I bsen y Zola, y sobrevolando sobre todos ellos el misticismo irracionalista schopenhaueriano. Relativismo y tragedia son los sentimientos de la sociedad alemana que 
ha sobrevivido y que vuelve a interrogarse sobre la irracionalidad del mundo.

No es de extrañar, por tanto, que en este clima psicológico la lucha encarnizada entre Fausto y Mefistófeles se agudice en la conciencia del creador. El Expresionismo así aparece como una nueva fase de la conciencia europea. Una etapa de irritación y de angustia, pero también de emergencia ante el peligro que de nuevo se aproxima. Podríamos afirmar que se está ante un Arte de premonición que se duele del pasado y presiente que el futuro apresura la catástrofe. Por ello, en sólo una década se innovarán todas las esferas de la creación desde la pintura y la literatura hasta la filosofía y el recién inventado cine. No hay ningún ámbito de la creatividad que no se renueve y transforme. La regeneración política y social únicamente puede venir de la negación. La negatividad se extiende por el arte y el pensamiento, culminando en una dialéctica negativa que será la herencia transmitida a las generaciones futuras por la Teoría Crítica. De este modo, de la resignación postbélica se pasa a la resistencia expresionista, y de ella a la agitación de las vidas y de las conciencias como harán los dramaturgos Toller y Brecht. Pintura y Teatro son las síntesis más elaboradas de las condiciones espirituales expresionistas. $Y$ a ellos se unirá el Cine, en cuanto nuevo Arte de Masas y del siglo XX. Las sombras así cobran vida. De la inmovilidad pictórica se llegará al movimiento consciente de la revolución cinematográfica de Lang o Murnau. La trayectoria creativa que lleva del Romanticismo al Expresionismo y de la Literatura al Cine no sólo tiene sus causas en los procesos históricos de la sociedad alemana en su paso del siglo XIX al XX, cuanto también en la profundización filosófica sobre la racionalidad y la irracionalidad de la sociedad moderna. La Modernidad que en Inglaterra ha generado la revolución liberal y en Francia ha conducido a la Revolución Francesa, en Alemania se ha gestado en una revolución intelectual sin precedentes. De "Leviatán" del empirista inglés Hobbes y de "La Enciclopedia" de los ilustrados franceses se llega en Alemania a la más monumental reconstrucción de la racionalidad en la obra de Kant.

La "Crítica de la Razón Pura" equivale a la arquitectura medieval, sólo que ahora es la arquitectura del pensamiento, -y sus capacidades y posibilidades-, la que se construye como el gran símbolo de los nuevos tiempos ilustrados. La confianza en la entrada de la Humanidad en su mayoría de edad y en la superación de los miedos irracionales resuena en el kantiano: ¡Sapere aude!. El "!atreverse a pensar ("será la consigna del Criticismo Kantiano que se extenderá al I dealismo de Hegel. Pero el concepto de razón que en la filosofía de Kant surgía como facultad de conocimiento humano, en Hegel se esparce por todo el Universo haciendo que todo lo real resulte racional. El despliegue de la Razón en la Historia necesariamente debe desenvolver la revolución de la consciencia por todas las sociedades (HEGEL, 1972).

El Romanticismo alemán, en consecuencia, refleja la energía de la 
razón, pero a la par se encuentra desamparado ante lo ilógico y lo instintivo. Otra vez la lucha de las conciencias de Fausto y Mefistófeles a las que Hegel dedicará uno de los más penetrantes y complejos estudios de su "Fenomenología del Espíritu". Lo finito y lo infinito, la libertad y el destino, lo consciente y lo inconsciente, son los polos en los que se articula el sentimiento trágico que lleva del Romanticismo al Expresionismo. La tragedia está inserta de manera inseparable en la conciencia de los creadores alemanes de la Modernidad. De Beethoven llegaremos a Schönberg, y de Hegel nacerá su negación en la obra de Nietzsche.

En donde mejor se observará esa fenomenología del espíritu en cuanto espíritu trágico, será en la Literatura que desde finales del siglo XIX desembocará en el Expresionismo. Si buscamos un símbolo de la dialéctica entre lo racional y lo irracional, nadie tan representativo como el poeta Novalis defensor, al mismo tiempo, de la ciencia y de la mística. Pero esta posición se va haciendo general en el movimiento de la "J oven Alemania" nacido en la época de Bismarck que con la obra de George Büchner pone los pilares de la Literatura comprometida con su tiempo y su sociedad.

Büchner se convierte en la referencia imprescindible del giro dado por la Literatura de la "Joven Alemania" hacia la expresión de lo social y lo político en cuanto parte esencial de la creación estética. En este sentido, si hay un punto de inflexión esencial éste no puede dejar de ser sino su tragedia "Wozzeck", auténtico drama en el que lo individual y lo colectivo, lo literario y lo político, confluyen en la tragedia del "hombre común", de los ciudadanos anónimos que a partir de este momento van a ir ganando lugar de protagonistas en la Literatura de entreguerras. La realidad se abre camino en el Arte del siglo XIX, del mismo modo que la industria aparece con categoría científica propia en el Positivismo filosófico y sociológico de Comte y Saint-Simón. Sin embargo, lo que desde una perspectiva positista es alabado como progreso, en el teatro la nueva sociedad industrial será representada en sus conflictos, en sus injusticias y en sus desastres de existencia $y$, específicamente, de conciencia. Woyzeck es el hombre-víctima, el ser maltratado por una sociedad que divide el mundo en verdugos y mártires. Es el final del optimismo positivista que inequívocamente se encamina al Darwinismo y al Nazismo.

No sería comprendido el Expresionismo en toda su complejidad sin detenernos más pormenorizadamente en el drama "Wozzeck" de Büchner. En él se encuentran las claves ideológicas y temáticas del Expresionismo posterior. El realismo psicológico preludia la concepción de la experiencia interior como representación de la realidad (MUÑOZ, 1998). En este sentido, "Wozzeck" encarna la doble realidad de lo cotidiano y de lo histórico. En cuanto experiencia cotidiana la miserable casucha, la taberna obrera, el ínfimo trabajo condicionan la existencia del hombre cuya experiencia histórica le ha convertido en soldado, en 
proletario, en asesino. En último término, en un ser sacrificado e inmolado ante el poder irracional de una sociedad ilícita por su injusticia. Pero en una cruel cadena, en una sociedad arbitraria, la víctima, a su vez, hace y crea nuevas víctimas. La mujer y el niño serán, también, los nuevos mártires del belicismo y de la jerarquización de la sociedad construida sobre la guerra y el clasismo. La escena final de la obra de Büchner que casi un siglo después Alban Berg convertirá en ópera, no deja dudas del vértigo indiferente de la cotidianidad cuando los niños relatan al hijo de Woyzeck el asesinato de su madre. La insensible frialdad de lo habitual refleja el endurecimiento de las conciencias alienadas durante siglos de explotación. El realismo psicológico, las filosofías vitalistas y el naturalismo literario componen los climas mentales en los que se despierta la sensibilidad alemana de principios del siglo XX. Sin embargo, bajo la aparente variedad de autores y corrientes, en todas ellas subyace una atmósfera de determinismo que consolida el triunfo de la voluntad irracional de Schopenhauer y del darwinismo de la herencia genética Ainmodificable. Nihilismo y pesimismo son las fuerzas que enmarcan la victoria de Mefistófeles sobre Fausto. El lado oscuro de un destino histórico derrotado se revela en un autor intermedio entre el Naturalismo y el Expresionismo como fue Gerhart Hauptmann. Pero en Hauptmann ya no hay protagonistas únicos sino grupales. La transición hacia un arte con héroes colectivos nos indicará la fractura social de entreguerras, pero asimismo las ilusiones de un cambio radical de sociedad y de valores. Nietzsche y Marx, Schopenhauer y Freud, irracionalidad y racionalidad, inconsciente y consciente, tales van a ser los ejes dialécticos de la creación intelectual y estética de la Alemania que se abre al siglo XX. Filosofía, Literatura, Música y Cine van a evidenciar la gran transformación del siglo: la aparición de las Masas en la Historia.

\section{Del pesimismo nihilista al optimismo revolucionario}

Si algo define la creación estética germana a lo largo del tiempo, es su absoluta imbricación en los acontecimientos políticos y sociales de cada época. Esto se hace evidente en el teatro expresionista que va de Frank Wedekind a Ernst Toller, pasando por Georg Kaiser. La Primera Guerra Mundial significó la agudización del sentimiento nihilista de una sociedad a la deriva. El agravio de las reparaciones de guerra que impuso el Tratado de Versalles, convierte al pueblo alemán en víctima de sí mismo y del antigermanismo surgido en Europa tras la contienda bélica. En estas circunstancias no es de extrañar que sea en 1910 cuando el movimiento estético del Expresionismo se imponga como reacción frente a impresionismos y simbolismos de finales del siglo diecinueve (MODERN, 1961).

El Expresionismo, por tanto, expresa lo real como existencia objetiva, pero existencia experimentada como experiencia interior $y$ anticonvencional. Precisamente, la ruptura de convenciones está en el 
origen de la desesperanza expresionista. Un mundo en ruinas, devastado por la guerra y desorientado por la quiebra de unos valores colectivos que han desembocado en la muerte de toda una joven generación. Y frente a la desolación popular, una naciente burguesía, enriquecida en el estraperlo y el contrabando, goza y se divierte sin percibir su entorno. La pintura de George Grosz explica mejor que cualquier otra creación, la decadencia moral, cultural y social del momento. Y, así, lo grotesco y lo ridículo llegan al paroxismo de los gestos y de las apariencias.

Dos Expresionismos literarios y estéticos se encuentran enfrentados, pero también paradójicamente estrechamente inseparables. EI Expresionismo realista y el Expresionismo revolucionario: Franz Wedekind y Ernst Toller. En ambos casos, la crítica social retrata la situación espiritual del desastre de la Primera Guerra Mundial. Frank Wedekind anuncia precursoramente la estética expresionista. Hay una perspectiva satírica centrada de manera especial alrededor de los prejuicios que acaban ahogando los mejores sentimientos y las experiencias más nobles y libres. En "Despertad de primavera" ("Frühlings Erwachen") se enfrentan dos mundos: el mundo de los adolescentes y el mundo de los adultos. El mundo de los adolescentes se sitúa en la escuela de una cerrada y agobiante ciudad de provincias. Tres personajes centran la acción: Melchor, bondadoso e inteligente; Mauricio, malicioso y astuto; Wend, inconsciente y cándida. Los tres jóvenes viven una sexualidad reprimida y culpable. Melchor será expulsado de la escuela por una primera experiencia sexual. Mauricio se suicidará por su fracaso colegial y su culpabilidad al inducir a Melchor a escribir su experiencia. $Y$ en el centro de este insano ambiente de profesores malvados e hipócritas y de alumnos maleados, se encuentra Wend quien morirá al someterse a las prácticas abortistas de una ignorante vecina que encarna el ambiente insalubre de toda esa cerrada sociedad.

Sin embargo, la obra finaliza sus cinco actos con un simbolismo casi metafísico. Un bondadoso desconocido salva a Melchor del suicidio cuando en el cementerio la sombra de Mauricio le incita a darse la muerte. Toda esta última parte recuerda los dramas románticos alemanes en los que hay una permanente reflexión sobre el sentido de la existencia, la bondad y la maldad, los prejuicios y la libertad. Pero el enfrentamiento entre adultos y jóvenes en esa asfixiante ciudad provinciana del "Despertar de primavera", se transforma en una lucha irreconciliable entre "dos sociedades": la sociedad "bien-pensante" y la sociedad amoral de postguerras. No obstante, las dos sociedades están entrecruzadas y mezcladas de forma absoluta, sin ningún contorno que diferencie a la una de la otra. Y por ello será Lulú ${ }^{3}$ el símbolo de la degradación moral de toda la colectividad. En "El espíritu de la tierra" y su continuación en "La caja de Pandora", asistimos a la representación coral de toda una sociedad sin principios ni reglas. 
Lulú es la protagonista de "La caja de Pandora" y del drama precursor el "Espíritu de la tierra". Casada la protagonista con el anciano Schwartz, seduce al pintor al que se le ha encargado hacer su retrato que, a su vez, es sustituido por Schoen un personaje de la misma catadura amoral que Lulú. La muerte de Schwart y del pintor ante el engaño que Lulú les ha hecho, finaliza con el suicidio de Schoen ante la existencia corrupta a la que Lulú le conduce. De manera que este personaje femenino trae la perdición de todos aquellos seres humanos que se cruzan en su camino. Perdición que en la segunda parte "La caja de Pandora" escrita por Wedekind en 1901, afectará a la misma Lulú.

Al salir de la cárcel, tras el suicidio de su marido Schoen, Lulú se ve obligada por su padre a ejercer la prostitución, sólo la equívoca condesa Geschwitz la trata con amistad. Es a partir del ejercicio de la prostitución cuando nos encontramos con los inicios del Expresionismo teatral. Prostitutas jóvenes, jugadores, borrachos, hampones, en general, todo un mundillo de lumpenproletariado componen "las alcantarillas" de la ciudad. Y en este ambiente asfixiante, Lulú acabará siendo asesinada por Jack el Destripador en una de las escenas más sórdidas del teatro contemporáneo. Sórdida y a la vez totalmente precursora de la estética expresionista. La pintura de George Grozs revolotea por todos los rincones de la obra. La decadencia de un mundo sin escrúpulos se va fraguando como "la sociedad normal" de una época que desembocará en una primera Guerra Mundial y en la antesala del Nazismo.

Sin embargo, tanto Wedekind como Hauptmann están reflejando el ambiente cosmovisivo de toda una época. La falta de principios y valores, el belicismo, la misoginia, la insolidaridad más absoluta y la injusticia más cruel aparecen como actitudes "naturales" de una sociedad en general desestructuración. En este contexto, resonarán los ecos nietzscheanos de la transmutación axiológica de un Zaratustra y los apocalípticos temores de un Spengler ante la decadencia de Occidente. Es por ello por lo que los inicios de la sociedad burguesa alemana de principios del siglo XX se van encerrando en una perspectiva nihilista y en un pesimismo antropológico e histórico sin precedentes. Y frente a esta situación va a resurgir la necesidad de dar un nuevo paso hacia el cambio y la transformación general del callejón sin salida en el que se ha confinado a la población alemana que ya es encaminada hacia la guerra. La revolución obrera, por consiguiente, se abrirá como la gran esperanza frente al triunfo de la barbarie y, así, la frase de Rosa Luxemburgo: (Revolución o barbarie!, va a resonar como resurrección humana y social.

Política y Arte se hacen inseparables en los comienzos del siglo pasado en Alemania. Expresionismo y Espartaquismo son términos que, aunque parecen aparentemente alejados, su vinculación va a quedar evidenciada a lo largo de las primeras décadas del siglo. El carácter burgués del Expresionismo que refleja una sociedad en descomposición social, política y cultural, no obstante va a cumplir una función de 
concienciación de las causas que han originado esa situación de desesperanza. La revolución espartaquista, en ese sentido, resulta una consecuencia de las contradicciones que han aflorado tras la derrota alemana en la Primera Guerra (BADíA, 1971). Pero, sobre todo, la formación del Espartaquismo significa un concepto nuevo y diferente de revolución del que había tenido la revolución bolchevique de 1917.

El concepto diferente de revolución del Espartaquismo nace de la evidencia de un fenómeno histórico nuevo: la aparición de la Masa en la Historia. Se está ante el primer movimiento revolucionario que percibe la transmutación del pueblo en masa y de ésta su tránsito hacia colectividad. Cuando Luxemburgo reafirma la necesidad de la espontaneidad de las masas, lo que está reivindicando no deja de ser sino el protagonismo creador y organizativo de una nueva estructura política, cultural y humana. Y ese protagonismo tendrá que romper con los viejos esquemas heredados del siglo anterior. Esquemas que son los que la revolución rusa ha recogido y con los que ha conducido su cambio de sociedad. Sin embargo, tales esquemas han vuelto a reproducir el concepto jerárquico de sociedad con el cual se quería romper de una forma radical (MICHELS, 1969). El problema, por tanto, será cómo establecer un modelo de sociedad diferente en el que el pacifismo, la libertad y la igualdad lleven a cabo los ideales expresados por Rosa Luxemburgo y Karl Liebknecht. De nuevo, el teatro y la literatura van a desbrozar el camino de los ideales de la sociedad revolucionaria. Y, así, el nihilismo desencantado del Expresionismo alemán emprende su tránsito hacia la reflexión revolucionaria sobre las posibilidades de una sociedad pacificada.

\section{Teatro, revolución y espontaneidad: la aparición de las masas en escena}

El teatro de Ernst Toller pone en el escenario las escisiones y conflictos de la sociedad capitalista y sus efectos sobre la población. Como había ocurrido con los dramas de Wedekind, Lulú y Wozzeck son las consecuencias humanas de una formación social en la que la explotación y la alienación cosifican y despersonalizan a los individuos. Lulú acabará siendo asesinada por J ack el Destripador como una prostituta más de las asesinadas por el sádico personaje. La mujer cumple, de este modo, con un trágico y despiadado destino que le impone el férreo papel sexual al que la sociedad burguesa la ha confinado. Wozzeck, por su parte, ha sido cobaya humana de una medicina que utiliza a los excombatientes como desechos y experimentos humanos, de soldado licenciado ha pasado a parado y alucinado individuo sumido en la ociosa locura de sus celos que le determinan al asesinato y al suicidio. Como se observa, en los dramas expresionistas de Wedekind los protagonistas se ven impulsados por fuerzas irracionales que viven como un permanente hado inmodificable. La irracionalidad de la muerte se muestra como la catastrófica voluntad que gobierna en toda sociedad injusta. Frente a 
ella únicamente se puede luchar colectivamente, pero en una colectividad que tome autoconsciencia de que "ese hado inmodificable" no proviene de una voluntad schopenhaueriana que gobierna el Universo, cuanto de la mala organización de la sociedad y de sus estructuras. Será en esta convicción de donde nace el teatro revolucionario post-expresionista, y de esta certeza surgirán los primeros intentos por expresar que el desorden proviene del orden que consagra la desigualdad, la enajenación y la explotación.

Uno de los dramas que señalará ese artificial desbarajuste social será, sin duda, "El Hombre-Masa" de Toller. Con "Los destructores de máquinas" el drama sobre "El Hombre-Masa" es, quizá, el teatro que se corresponde con la revolución espartaquista y sus ideales (TOLLER, 2002). Escrito en la cárcel en el trágico año 1919, -asesinato de Rosa Luxemburgo, fracaso de la revolución espartaquista y encarcelamiento de éstos en la prisión-fortaleza de Niederschönenfeld-, Toller reflexiona sobre el valor de la lucha por la emancipación humana y colectiva. Esta reflexión le lleva a encarar uno de los temas que van a transformar la reflexión social en el siglo XX: el tema de las Masas y su comportamiento.

Se puede decir que la aparición de la población convertida y "organizada" en forma de Masas imprime un giro nuevo a la Teoría Sociológica y Social. Con la masificación de las ciudades, como consecuencia de los cambios del paso del capitalismo industrial al capitalismo de tipo monopolístico y financiero, se asiste a unas modificaciones sin precedentes del análisis referido a las estructuras de socialización y psicológicas de la colectividad. Los Psicólogos de las Multitudes como Gustave Le Bon y Frederic Tarde, desde una posición conservadora, van a formular nuevos planteamientos sobre la conducta de las Masas (LE BON, 1987). La ley de la unidad mental de las multitudes, según la cual "hay una tendencia a que los coeficientes intelectuales más torpes actúen rebajando al resto de coeficientes", se constituye en unos de los pilares centrales del desprecio elitista al funcionamiento de la nueva sociedad. Pero lo grave de la nueva Psicología de las Multitudes será que va a introducir algunos de los tópicos más perdurables algunos paradigmas de la Ciencia Social y Política posteriores (HARRIS, 2000).

Entre esos tópicos que se repetirán en el Historicismo biologicista de Oswald Spengler o en el Vitalismo irracionalista heredado de Nietzsche, van a ser determinantes los siguientes:

- Que las Masas se comportan siempre con criterios de irracionalidad.

- La concepción de la necesidad de un líder que dirija y gobierne con "mano de hierro" a las multitudes.

- La teoría de la decadencia que la conducta de las multitudes ejerce sobre "los grupos superiores y élites" de la sociedad.

- Y, desde luego, la contraposición entre minorías-mayorías que va a convertirse en una constante de ciertas posiciones teóricas posteriores. 
Desde Pareto hasta Freud encontraremos en el análisis sociológico y psicológico tal preocupación por el fenómeno nuevo que va a marcar a todo el siglo XX como se verá más adelante en nuestro estudio (ZEITLIN, 1987). Sin embargo en la Literatura, y en concreto en la creación teatral, el fenómeno va a ser recibido desde posiciones estéticas renovadoras. Frente al teatro burgués, anclado en temas manidos y subjetivistas, va a nacer un teatro revolucionario que refleja los conflictos de las multitudes y que su lógica evolución culminará con la invención y la conversión del Cine en Arte. En esta posición revolucionaria Ernst Toller encabeza la cristalización de los ideales luxemburguistas de la toma de autoconciencia de la colectividad maltratada y explotada a lo largo de la Historia.

La reflexión sobre la necesidad de la toma de conciencia en las clases alienadas por el modo de producción serializado del capitalismo industrial tendrá en Giorgy Lúckacs uno de sus mejores teóricos. En "Historia y conciencia de clase" se retoman los temas hegelianos que Marx había conceptualizado como superestructurales. La ideología, el fetichismo y la cosificación reaparecen como el armazón teórico desde el que reconstruir el estudio de los efectos del capitalismo sobre la psicología humana. La psicología humana será el elementos más dañado por una economía que humaniza los objetos y, al mismo tiempo, cosifica a los individuos humanos. Es la inversión de la inversión, y si Marx puso a Hegel sobre sus pies, Lúkacs va a tratar de poner a Marx sobre la cabeza para denunciar la mutilación de las conciencias colectivas por la acción del interés económico privado (LUKÁCS, 1978). Esta será también la gran influencia marxiana recogida por Rosa Luxemburgo en su "Acumulación del capital" (LUXEMBURGO, 1967). Tanto para Lúkacs como para Luxemburgo, el espectáculo de la muerte diaria en las fábricas también es el espectáculo de la muerte en las trincheras, y fundamentalmente de la destrucción de la conciencia colectiva y de sus estructuras de lucidez y conocimiento.

Por tanto, el Neomarxismo de comienzos del siglo XX acusa a quienes trafican con la conciencia de la colectividad e impiden su emancipación como seres racionales y libres. Solo así es como es posible comprender la valentía del teatro épico de Brecht o del Expresionismo revolucionario de Toller. En sus obras se muestran las argucias del poder que esclaviza a hombres, mujeres y niños con unas cadenas, que como en tiempos pasados, atan a la población a la rueda de una nueva sumisión y de una ignorancia dirigida. Y si en tiempos pasados la esclavitud era encadenada con cadenas de hierro; en la nueva, los cautivos están confinados a una cadena temporal con un horario que impide el disfrute del tiempo de la vida a los trabajadores del capitalismo postindustrialista. En estas condiciones, las salidas van a ser diversas y radicales. Desde los destructores de máquinas que el Luddismo propagó por fábricas y talleres, hasta el sabotaje que, no obstante, fortalecía los mecanismos represivos del capitalismo postcolonial. Todos estas luchas 
y enfrentamientos se recogen en la obra de Toller. En "Los destructores de máquinas" se afrontará la oposición y hostilidad obrera frente a la máquina y la técnica. La destrucción de las herramientas de producción se concibe como la salida de la explotación a la que es conducido el proletariado industrial. Sin embargo, y como muy bien había subrayado Marx en "El Capital", relaciones y fuerzas de producción no eran ni significaban la misma cosa. La destrucción, por consiguiente, de las máquinas acababa empobreciendo más aún al grupo obrero, ya que con la aniquilación de la máquina no se acababa, ni mucho menos, con el drama de la cosificación y la humillación de los trabajadores.

Ahora bien, en la Alemania de principios del siglo XX, la perdida de la Primera Guerra Mundial y, sobre todo, las detestables y rencorosas imposiciones del Tratado de Versalles inciden en "el clima mental" de una sociedad que se siente arrollada por sus élites. El Expresionismo, como concepción del mundo, es el mejor exponente de la situación anímica de la población alemana. Es por ello por lo que todo recibirá la marca de la deformación y de la anomalía. Desde el movimiento del "Brücke" hasta las últimas pinturas alemanas de Grosz, la sensación de falseamiento de la realidad se hace omnipresente. Especialmente, el teatro y el inicial cine expresionista reflejarán como ningún otro arte cómo los individuos son avasallados y pisoteados por los intereses económicos y políticos gobernantes. Y de esta percepción, el teatro expresionista de Ernst Toller nace como la precursora acusación de hacia dónde se dirige el capitalismo que convierte a la población en masas, y a las masas, en momentos de conflicto, en soldados y en la carne picada del "tartar", como cantará la célebre e irónica canción de Bertold Bercht.

En el "Hombre-Masa", por consiguiente, culmina la visión revolucionaria del Expresionismo hasta la llegada del teatro de Bercht. En los siete cuadros que componen la obra se presentan los conflictos $y$, también, los ideales del movimiento obrero en un año tan determinante como fue mil novecientos diecinueve con la derrota del Espartaquismo y el asesinato de sus líderes. Estamos ante un texto innovador por su forma y contenido. La escena queda estilizada de tal manera que los personajes son representados como alegorías simbólicas. La Mujer, el Hombre, el Sin Nombre, los Prisioneros, los Obreros o las Sombras forman un complejo cuadro en el que acción e ideas se intercalan alegóricamente. La Mujer significa la Humanidad y sus ideales de progreso y humanización, el Hombre resulta la alegoría del Estado Burgués, los Obreros y Prisioneros se muestran como las víctimas de la Historia, pero será el personaje de los Sin Nombre el que exprese a la naciente Masa que se convierte en Ael juguete de Banqueros y Militares. Será, por tanto, el personaje de los Sin Nombre el que la Mujer buscará liberar de su opresión presente, pero también precursoramente de su alienación futura. Es muy significativa la diferencia que Toller establece entre los Obreros y los Sin Nombre. Frente a la revolución defendida por 
los Obreros, los Sin Nombre apoyan la violencia. Entre ambos, la Mujer se alinea con los Obreros, pero rechazando cualquier forma de violencia. En el quinto cuadro en el que estalla la revolución y la Mujer es apresada y encarcelada se percibe cómo Toller relata y reflexiona sobre los acontecimientos de la derrota Espartaquista. Así, la oposición de la Mujer a escapar de su prisión asesinando al carcelero, expone los ideales del pacifismo luxemburguista y su antagonismo a la guerra como la forma más sofisticada de la violencia capitalista-burguesa.

El fusilamiento de la Mujer y la derrota de los Obreros son descritos por Toller no como el desastre de la revolución, sino como el ascenso de los Sin Nombre, de los Hombre Masa. En la obra se intuye el desánimo de la intuición del advenimiento de una sociedad despersonalizada en la que los Banqueros dominarán a su gusto y capricho la vida humana. Una escena resulta indicativa de este terrible panorama. Es la escena del "fox trot" de los Banqueros alrededor de las monedas de oro en la inmensa y gélida sala de la Bolsa. En "Metrópolis" de Fritz Lang aparece una escena similar en la que los capitalistas danzan en su optimismo bélico ante un panorama de batallas y conquistas imperialistas que les favorecen en sus dividendos. Eros y Thanatos se interrelacionan en el parquet bursátil (FREUD, 1970; 1974. v. 8, p. 3017-3068).

La masificación se intuye ya como el problema de problemas del siglo $X X$. Frente a los movimientos revolucionarios en los que la consciencia prevalece en la planificación de sus acciones, la población sometida a la masificación impersonal se va a significar por su inconsciencia. En "La Psicología de Masas y análisis del yo" (FREUD, 1969; 1974, v. 7, p. 2563-2611), Freud supera los análisis mecanicistas de Le Bon y Le Play, estableciendo los mecanismos compensatorios que las despectivamente llamadas "multitudes" desarrollan en cuanto mecanismos de defensa ante el medio hostil. Mas, para Toller, "ese medio hostil" tiene un nombre muy claro y definitorio: capitalismo. De este modo, el Hombre Masa entra más tempranamente en la Literatura que en la Psicología. La obra teatral de Toller es anterior al libro de Freud y su ventaja ideológica estará en la sinceridad de los precursores. Sinceridad que llevará a Ernst Toller al suicidio en 1939 cuando la Historia, definitivamente, se divide ya en minorías y mayorías, en líderes y en masas electrizadas por la demagogia del capitalismo tecnológico.

\section{La máquina y la alienación: "Los destructores de máquinas".}

En el "Hombre Masa" Toller percibía el problemas esencial del siglo XX: la despersonalización a la que el capitalismo iba a someter a las poblaciones reducidas a la esclavitud del trabajo serializado. En "El Capital", Marx ya analizaba algo que iba a ser el fundamento de la despersonalización, es decir, la alienación en cuanto perdida de las propias capacidades humanas por efecto del sistema económico de producción capitalista, se va a convertir en el problema determinante de la nueva sociedad construida sobre el dinero y la ganancia para unos 
pocos, la clase dominante. La contraposición, pues, entre dominados y dominadores equivale a la oposición entre élites y colectividades en "El hombre Masa" de Toller. Sólo que, ahora, en "Los destructores de máquinas" nos vamos a sumergir no tanto en la destrucción de la psicología colectiva, cuanto en la devastación del mundo humano a través del dominio de las máquinas y de los artefactos utilizados y conjurados en contra de las mismas facultades y capacidades humanas. Lo monstruoso del uso de la máquina en el capitalismo provendrá de su poder extraño y ajeno a cualquier aspecto que recuerde lo humano. En "Los Manuscritos de Economía y Filosofía" Marx advertía:

\footnotetext{
"Por eso el trabajador asalariado sólo se siente en sí fuera del trabajo, y en el trabajo se siente fuera de sí. Está en lo suyo cuando no trabaja, y cuando trabaja no está en lo suyo. Es un trabajo forzado... El trabajo ya no es la satisfacción de una necesidad, sino el medio para satisfacer las necesidades fuera del trabajo."(MARX, 1974, p. 109)
}

Marx establece una dialéctica entre lo humano y lo animal, pero la mediación entre los dos modos de ser estará en la máquina. El autoextrañamiento es la exigencia de un modo de producción que exige convertir a los individuos en máquinas y, a la inversa, a las máquinas las personaliza. Esta descomunal crueldad modifica las herramientas del trabajo. El hombre será lo mecánico y los artilugios maquinales tomarán el lugar de los hombres. Pero la lucha hombres-máquinas será una falsa lucha, porque el dueño de la máquina quedará escondido entre los recovecos del malvado y despiadado mecanismo. Tal fue el error del Luddismo y sus acciones de sabotaje.

Toller encarará, entonces, las luchas obreras desde los inicios de la heroica resistencia de los productores a ser convertidos en cosas. La revolución industrial consolida en el siglo XIX una organización económica y social en la que la división del trabajo encasilla a los individuos en función de su pertenencia a clase dentro de los procesos de producción material. En estas condiciones, los campesinos emigrados, a causa de la miseria rural, hacia las primeras urbes capitalistas se van a ver sumergidos en "otras formas de miseria" más planificadas y peligrosas. Charles Dickens describió la pobreza exacerbada de los barrios obreros y la avaricia de la clase burguesa que hacía de la desgracia obrera su fortuna y privilegio.

Así al dividirse la sociedad capitalista en dos clases irreconciliables, los conflictos interclasistas van a definir la sociedad civil y la formación del Estado de la burguesía. Pero, en esa división del trabajo en la que la clase obrera se verá reducida a ser una simple parte de la maquinaria puesta en marcha por la clase burguesa con el objetivo de apropiarse de los bienes materiales, los movimientos de protesta y rebelión van a ser de muy diferente y desigual signo. El Luddismo, en este punto, nace en la industrial textil británica para hace frente a la introducción de nuevos 
telares más rápidos e inhumanos. La fábrica deviene en cárcel y en ese "paisaje" desolador pasará su existencia la clase mutada en mero objeto.

Es imprescindible antes de seguir hablado de "Los destructores de máquinas" de Ernst Toller referirnos a uno de los aspectos que mayor relevancia va a tener en los escritores, filósofos y teóricos más conscientes del siglo XIX. Desde Dickens hasta Balzac y Zola, pasando lógicamente por Marx y Engels, se aprecia una situación de sobrecogimiento ante lo que está ocurriendo con la instauración de la sociedad industrial. Las mentes más lúcidas y clarividentes ven con horror cómo hombres, mujeres y niños son apresados en una nueva esclavitud más sofisticada y perversa. En la máquina textil está el paradigma de la nueva sociedad de clases. Niños sin infancia que desde los cinco años entran en la cadena de producción, mujeres que de la cadena pasarán a la prostitución "como lógico destino" de su pobreza, hombres que no llegarán a los cuarenta años porque la enfermedad adquirida en el trabajo y los vicios con los que olvida a éste, son los protagonistas de las mejores obras literarias del XIX. "La Taberna" y "La bestia humana" de Emilio Zola nos expresan la condición de la miseria y su degradación humana y vital. Pero, a la par, también el explotador es reflejado en el Realismo. En "Eugenia Grandet" de Balzac entramos en la casa doméstica y en las relaciones familiares del nuevo prototipo humano que se ha ido conformado bajo las nuevas formas capitalistas: la psicología condicionada y determinada por el dinero. Eugenia Grandet, hija de una clase acomodada, es paradójicamente otra víctima de la sociedad de clases. El proletariado ha sido reducido a la condición de cosa y asimismo, la cosa-dinero reina y gobierna unas relaciones familiares y humanas sumidas en la pobredumbre y en la corrupción. El extrañamiento que experimentan las conciencias más lúcidas, es sin duda un proceso esencial para entender la creación intelectual del siglo XIX. El dinero y la máquina se han apropiado de los humanos. Como si de una invasión de seres de otro planeta se tratase, los burgueses se han implantado en la tierra con la malvada intención de colonizarla y esclavizarla. Europa, América, Asia y África sufrirán a los avariciosos burgueses que en su ceguera ambiciosa oprimen pueblos y sociedades, arrollan con sus negocios bélicos a generaciones enteras y ultrajan el significado de género humano con sus insaciables deseos de riqueza. Las resistencias ante "un orden" en perpetuo desorden serán una constante situación de la sociedad industrial. De las rebeliones a las revoluciones sólo habrá un mínimo y pequeño paso. Del Socialismo Utópico de Saint-Simón al Marxismo únicamente será imprescindible agudizar los análisis en profundidad de las causas de Ala miseria de las naciones. Sin embargo, hasta la llegada de la investigación marxiana, los experimentos revolucionarios consistirán en rebeliones románticas y el Luddismo de todas ellas será la más significativa.

La destrucción luddista de las máquinas será expuesta por Toller en su

Estud. pesqui. psicol., Rio de Janeiro, v. 11, n. 1, p. 197-224, 2011. 
drama "Los destructores de máquinas" como una reflexión sobre qué hacer ante las contradicciones de la nueva sociedad capitalista. Toda la obra está construida como un inmenso tratado sobre la explotación económica, social y humana. Pero, a la par, en la obra hay una contraposición entre rebelión o revolución. La rebelión destruirá máquinas y fábricas. La revolución busca cambiar lo que está oculto: la explotación. En esta dicotomía transcurre todo el drama de Toller. Para los ludditas las máquinas tienen que ser destruidas y desmontadas. Sus argumentos son apasionados y hermosos. Los telares aprisionan como un nuevo Sísifo que nunca logra coronar la cima con sus esfuerzos.

Ahora bien, si en el "Hombre Masa" se asistía a una alegoría sobre la nueva tipología sociológica en la que se iba a encuadrar a la clase obrera, en "Los destructores ..." la personalización de los protagonistas de la obra resulta un recurso escénico con la finalidad de crear identificación en los espectadores con los personajes. Las luchas obreras son recogidas con sus contradicciones, dudas y equivocaciones. Hombres, mujeres y niños aparecen en escena de una manera realista. Sin embargo, Toller siempre introducirá alegorías no expresas. En este caso, la máquina es el símbolo no manifiesto, pero permanente en el trasfondo de la situación.

La máquina es metáfora y emblema del capitalismo. Como pocos años después del drama de Toller hará Fritz Lang en "Metrópolis", la máquina engullirá en su vientre a las filas obreras como si de un gigante mitológico se tratase (KRACAUER, 1985, p. 142 y sigs; también ver EISNER, 1988, p. 159-169). El monstruo industrial devora ciegamente, mientras "en el paraíso" privilegiado el ojo del empresario vigila los más mínimos movimientos de los obreros. Lang precursoramente nos muestra la ciudad de la vigilancia en donde monitores observan para velar por las ganancias de sus propietarios. La maquinaria, de este modo, espía todos los movimientos, pero esencialmente los pensamientos y sentimientos de sus dominados. La alegoría se ha hecho verdadera, con el paso de las décadas posteriores, tanto al drama de Toller como al film de Lang. Y en su objetividad, la explotación colectiva de principios del siglo $X X$ se ha unificado con la alienación general, también colectiva, del siglo XXI. Será por ello por lo que el Expresionismo sigue tan vivo y presente como en sus primeros años de creación. Pues bien, la derrota del movimiento Luddista será previsible en la obra de Toller. La destrucción de las máquinas sume en el paro y la miseria a los obreros. La ruptura de la maquinaría no conllevará la aniquilación del capitalismo. Marx lo percibió conscientemente. Los medios de producción y las fuerzas de producción son una parte del sistema, pero no son el sistema en su globalidad. El Capitalismo, por tanto, se estructura de una forma más compleja que lo que explicaron Saint-Simón o Proudhon. Como no recordar aquí uno de los textos más grandes del pensamiento de todos los tiempos: 


\begin{abstract}
"En la producción social de su existencia, los hombres entran en relaciones determinadas, necesarias, independientes de su voluntad. Estas relaciones de producción corresponden a un grado determinado de desarrollo de sus fuerzas productoras materiales. El conjunto de estas relaciones de producción constituye la estructura económica de la sociedad, la base real, sobre la cual se eleva una superestructura jurídica y política, y a la que corresponden formas sociales determinadas de conciencia. El modo de producción de la vida material condiciona el proceso de vida social, política e intelectual en general. No es la conciencia de los hombres la que determina la realidad. Por el contrario, la realidad social es la que determina su conciencia". (MARX, 1970, p. 42-43).
\end{abstract}

Marx mira así debajo de la alfombra del Capitalismo y encuentra un esqueleto que no es sino la anatomía de la usura: la plusvalía. Toller ha puesto en evidencia que la destrucción de los instrumentos de producción no ha implicado la liberación de los individuos. Muy al contrario, nuevos males ha conllevado esta rebelión romántica. El empresario ha quedado indemne. El paro resurge como un castigo no deseado por los rebelados. Luego, la realidad del Capitalismo necesita para su aclaración acudir a las mejores tradiciones intelectuales que la Humanidad ha creado a lo largo de la Historia. Y en esas tradiciones, la Ciencia Económica permite desvelar el halo de misterio que envuelve a un sistema en el que su dios y creador es el dinero.

En consecuencia, la forma abstracta del Capitalismo necesita una investigación muy pormenorizada de sus estructuras profundas. Esta investigación confirma a Marx la necesidad de entender que el sistema de contradicciones capitalistas no se resuelve meramente destruyendo los medios de producción. Al contrario, la pervivencia de este modo de producción se concentra en "algo" tan poco perceptible como el concepto de valor. Pero el valor entendido a partir de otro concepto: plusvalía. Así, la plusvalía es la fuerza de trabajo no remunerada e intensivamente utilizada por el empresario. Con este análisis de Marx, el Luddismo queda relegado a una furia espontánea de los trabajadores ante su explotación, mas no logrará alterar en ningún sentido el carácter acumulador y destructivo del Capitalismo.

Toller desarrolla una representación dramática sobre la ingenuidad de una rebelión obrera en los inicios de la Revolución Industrial que no haya valorado la capacidad destructiva y represiva del Capitalismo. Sin embargo, en "Los destructores de máquinas" no sólo se asiste a la revuelta de los tejedores ingleses, cuanto que lo que está en el sustrato de la obra no describe sino la visión que, tres años después de la Revolución Espartaquista, Toller se plantea en relación a su fracaso. "Los destructores..." , en suma, fue escrita en mil novecientos veintiuno y supone una profundísima reflexión sobre temas que llegan hasta nuestros días como, por ejemplo, el papel de la máquina en la explotación social, la insolidaridad-solidaridad de la clase obrera, el 
sufrimiento de la gran mayoría de la población ante el dominio irracional del dinero, la infancia deshecha por el trabajo en la fábrica ..., y en todos estos temas hay un elemento que el autor destaca: el carácter destructivo de la economía capitalista. La hondura con la que en el drama se expone el proceso de explotación, y sus consecuencias sobre una humanidad cada vez más indefensa, alcanza una honradez ética e intelectual cuya continuidad posterior tendrán las obras expresionistas y post-expresionistas de Brecht y Dürremat.

Un aspecto, no obstante, tiene que destacarse como reflejo del gran debate que los movimientos revolucionarios aportan en los años veinte del siglo pasado. El tema de la espontaneidad de las masas se superpone tanto en "El Hombre Masa" como en "Los destructores de máquinas". El Espartaquismo de Luxemburgo y Liebknecht defendió la capacidad organizativa de la clase obrera frente al burocratismo de un tipo de partido político sumamente jerarquizado y subordinado. Rosa Luxemburgo propugnará un modelo revolucionario de consejos obreros autónomos no dirigidos "por líderes carismáticos" ni caudillistas (LUXEMBURGO, 1976). La polémica entre Lenin y Luxemburgo presagia una de las problemáticas centrales de los movimientos obreros. En este sentido, el pacifismo y no dirigismo del movimiento Espartaquista va a quedar en la Historia de los Movimientos Sociales como uno de los grandes precursores de la concepción autoorganizativa de los cambios revolucionarios.

El mismo Ernst Toller será un espartaquista activo. Participará en la revolución de mil novecientos dieciocho en Berlín y en Baviera ocupará la presidencia del Consejo Obrero que trata de establecer la República de Consejos Obreros en Alemania. Sin embargo, la derrota del Espartaquismo llevará a Toller a la cárcel durante cinco años en los que, al mismo tiempo, escribirá sus obras más representativas convirtiéndose en gran medida en el dramaturgo más relevante del movimiento luxemburguista.

Los años de cárcel de Toller fueron años de gran creatividad. El "Hombre Masa", "El alemán cojo", "Hinkemann" y "Los destructores de máquinas" pertenecen a esta etapa. Aún escribirá "Hurra vivimos" que sumados al "El libro de las golondrinas" y "El día del proletario: requiem por los hermanos asesinados", componen una obra única en defensa del movimiento obrero y revolucionario. Se podría considerar que Toller expresa mejor que ningún otro autor el Expresionismo Revolucionario. No hubo causa obrera en la que el autor expresionista por participara en los años veinte y treinta del siglo pasado. Después de su acción política en la República de Consejos Obreros de Baviera y por la que estuvo encarcelado hasta el año veinticuatro, vendrá a España en plena Guerra Civil en mil novecientos treinta y ocho. Momento éste en el que ya Hitler está en la Cancillería alemana y comienza la preparación de la posterior invasión de Polonia. En estas condiciones, Toller creará el "Spanish Relief Plan" de ayuda a los niños republicanos españoles. La totalidad de 
la existencia del dramaturgo revolucionario se pondrá al servicio de los más débiles. Financiará con sus recursos la ayuda a los niños de la República, pero asimismo luchará en todos los frentes posibles frente al Fascismo y al Nazismo. España y Alemania serán sus horizontes geográficos e ideológicos. En Barcelona asistirá a la llegada de Franco a la ciudad y en Berlín conocerá el incendio del Reichtag y el encarcelamiento de sus amigos comunistas. El pesimismo empieza paulatinamente a hacer mella en el espíritu de Toller. Su exilio, en mil novecientos treinta y nueve, a Estados Unidos y su suicidio en un miserable hotel de Nueva York recuerdan el drama de todo un siglo: el siglo XX.

\section{Conciencia expresionista y conciencia crítica.}

El Expresionismo pese a su importancia y trascendencia posterior, sin embargo, fue un movimiento que apenas se prolongó más de una década desde su fundación a principios del siglo pasado. Ahora bien, pese a la corta vida histórica del movimiento, su influencia e influjo será esencial a la hora de entender en profundidad el estado de las conciencias y las cosmovisiones del siglo XX. En este sentido, el desarrollo del movimiento expresionista coincidirá con los prolegómenos de la Primera Guerra Mundial y su estallido. Es la época en la que se propugna "la unión sagrada" alemana y en la que se empiezan a observar los atisbos de una mentalidad autoritaria de futuras y terribles consecuencias. Pero, también, a partir de mil novecientos diez, angustia y revolución van a ir de la mano. Ello se empieza a percibir en los iniciales poetas expresionistas, especialmente en Else Lasker-Schüler y Ernst Stadler. El sentimiento de inquietud y de malestar se impone en la conciencia de una juventud rebelde que añora la tormenta y el ímpetu (Sturm und Drang) del pasado y, asimismo, la sublevación ante el presente (SCHNEIDER, 1956).

El Expresionismo, en definitiva, será una actitud ante la existencia y la sociedad. Una profunda e inquietante agitación del espíritu se adueñará de una generación que no quiere hacerse cómplice con la decadencia de una clase social dominante que explica su propio declive como el ocaso de toda la civilización. Oswald Spengler, así, en su "Decadencia de Occidente" identificará la crisis de la burguesía belicista con el final apocalíptico de "una edad civilizada" y el advenimiento de "los nuevos bárbaros". El "final de la Historia" aparece y reaparece de continuo cuando el grupo hegemónico ve peligrar algunos de sus privilegios. Será, efectivamente, el final de la Historia, pero de la Historia de una élite que, de inmediato, será sustituida por otra. Sin embargo, en ese momento de crisis las conciencias se agudizan y la lucidez hará crujir los estancados chasquidos de la convención. La sociedad convencional y desencajada de principios de siglo que va a conducir a toda una generación al matadero de la guerra, estará en el origen y germen del rechazo expresionista a la dominación. Rechazo que guía la actitud 
revolucionaria de los Espartaquistas y, a la par, acelera la aparición del pensamiento crítico. Y, sobre todo, precipita el estallido de la necesidad de un cambio radical de época. Una transformación epocal, como afirmarán después los filósofos existencialistas.

La agudización de la conciencia crítica en la Literatura germana había sido iniciada por George Büchner. La denuncia de una sociedad corrupta y clasista está en el sustrato profundo de la actitud de rebeldía expresionista. La herencia de Büchner, en consecuencia, va a ser recogida no sólo por los jóvenes dramaturgos (Hans Johnst, Georg Kaiser o Ernst Toller), cuanto por pintores y músicos. Grosz y Berg son la imagen y el sonido de la época. Y aquí estará el puente de unión con los filósofos críticos. El joven Adorno recogerá de Berg la disonancia angustiada de Lulú y Wozzeck, convirtiéndola en pensamiento dialéctico y negativo. La negatividad, en consecuencia, entrará arrolladoramente como Expresionismo filosófico y social llevado hasta sus últimas consecuencias.

Si Ernst Toller reflejó los ideales Espartaquistas en sus obras, Brecht avanza hacia el Marxismo mediante la actitud distanciada. Ese gesto distante ante la realidad que en el teatro de Brecht se nos ofrece, deviene en postura disidente en el pensamiento de la Teoría Crítica. Pero esta disidencia se ha ido conformando en la primera educación juvenil de los autores de Frankfurt y, en concreto, en la profundísima influencia que su profesor de Secundaria dejará tanto en Horkheimer como en Adorno y Benjamin: Sigfried Krakauer.

Kracauer como Berg serán los hilos ocultos del tejido crítico con los que se van a tejer gran parte de la urdimbre teórica de la Escuela. Adorno viajará a Viena para conocer las complejidades de la nueva tonalidad dodecafonista creada por Schönberg. Mas, no sólo se va a introducir en un universo de sonidos cuanto de conceptos e ideas. En la opera "Lulú" la crítica social a una sociedad caracterizada por el cinismo y el disimulo va a ser determinante para un joven Adorno que aún no ha decidido su rumbo profesional futuro. El conflicto social, el autoritarismo, la miseria de la conciencia, el belicismo y la corrupción de una Socialdemocracia que en mil novecientos diecinueve ha asesinado fríamente a Rosa Luxemburgo en el automóvil que la lleva a la prisión. Horkheimer afirmará entonces que ese día de enero comenzó el Nazismo en Alemania. La frialdad, el burocratismo, la crueldad disimulada, son transmitidos como el espíritu de la época. Kafka ya está presente en "EI Grito" de Edward Munch y en "El Proceso" kafkiano ya se siente en "la jaula de hierro" de Weber y en "la razón instrumental" de Horkheimer. Se podría considerar la perspectiva expresionista como una representación anímica de una sociedad que se encamina hacia el desastre bélico. La disonancia expresa el conflicto de una época en la que se está asentando el capitalismo que, como afirmó Marx, deja como única relación humana "la callosidad del dinero". En ese mundo chirriante de los negocios que hacen de la muerte un activo bancario, la 
guerra se eleva sobre el resto de instituciones y organismos como una transacción más en los beneficios y en los intercambios. El malestar en la cultura, al que se va a referir Freud, será el definitivo triunfo de Thanatos sobre Eros. Y así en la década de los años veinte y treinta del Siglo XX, el principio de destrucción revoloteará como un insaciable buitre por los cielos europeos. Esa percepción del desastre ya había sido anunciada por los apocalípticos teóricos del conservadurismo y del darwinismo social. Spengler en su "Decadencia de Occidente" clamaba por la quiebra de la sociedad burguesa asediada por los "nuevos bárbaros". Esta situación de ansiedad en las nacientes poblaciones convertidas ideológicamente en masas, ya se describía en la freudiana "Psicología de Masas y análisis del yo". Para Freud, el peligro de la irracionalización de las poblaciones significaba un mecanismo de relojería puesto en marcha. Y este mecanismo era más fácil de detonar de lo que era previsible. Por ello, acercarse a la Alemania de la República de Weimar era aproximarse al abismo, a la disonancia , a la dislocación.

Hay una Weltanschauung cosmovisiva que se presiente en el Arte, en la Música, en la Pintura y en la Filosofía. El profeta Nietzsche ya anticipó la "voluntad de poder" y la necesidad del cambio de los valores. Pero el Superhombre se está fraguando no como un Zaratustra renovador, sino como la salvaje antesala de Goebbels. Por ello, la necesidad de la Teoría Crítica es un imperativo ante los chirridos y las disonancias. La aparición de la primera y única Escuela de Frankfurt en 1923-1924 significa la síntesis de síntesis ante la quiebra de la racionalidad y del pensamiento. Explicar la identidad entre Expresionismo, Dodecafonismo y Teoría Crítica es tratar de aclarar el estado anímico de unas sociedades devastadas. En la Gran Guerra, todos han perdido. Bueno, ... no todos. Poderosos negocios han florecido al calor del estraperlo y del mercado negro. La prostitución y la demencia se han incrementado, como se dibuja en las pinturas de Grosz. La Lulú de Alban Berg será el destino femenino, Wozzeck el sino obrero. En la destrucción, sin embargo, se firman transacciones millonarias, sólo que ahora los negreros coloniales han tomado otro aspecto: la apariencia del asustadizo "buen burgués" que esconde sus vicios bajo la forma de "buen ciudadano" La personalidad autoritaria está a punto de cristalizar en la teoría. Y en esa cristalización los "Estudios sobre autoridad y familia" (HORKHEIMER, 2000) del Instituto para la Investigación Social dirigido por Max Horkheimer serán en donde se afilen los primeros conceptos y temas que desemboquen décadas después en el hombre unidimensional.

Era, entonces, una necesidad cantada la formación de la Escuela de Frankfurt. Todo anunciaba su llegada. Como mesías de un tiempo nuevo y diferente, Horkheimer, Adorno, Benjamin, From, Marcuse, Kirchheimer, Pollock ..., en un primer momento, van a componer el espíritu de una época, como anunciara Hegel un siglo antes al referirse a los cambios que la Revolución Ilustrada traía a Europa. Pero, en la 
República de Weimar, el Volkgeits se va a imponer irracionalmente con esa irracionalidad que sólo la Socialdemocracia sabe camuflar tan ladina y disimuladamente.

La fundación del Instituto de Investigación Social nace del interés por reconstruir, en un primer momento, la historia del movimiento obrero. La herencia del comerciante en trigo que fue el padre de Félix Weil posibilitó crear el fondo necesario para establecer los primeros pasos del Instituto bajo la dirección de Carl Grünberg. Sin embargo, será en mil novecientos treinta cuando asuma la dirección Max Horkheimer el momento en el que ya se puede hablar de la que va a ser una teoría imprescindible para comprender las transformaciones del capitalismo industrial en postindustrial, y en su posterior tránsito de postindustrial a capitalismo tardío. De este modo, no es de extrañar que el primer texto "Teoría tradicional y teoría crítica" (HORKHEIMER, 2002) nazca para precisar muy pormenorizadamente lo que era propio de la posición convencional de análisis social, de lo que define y caracteriza el significado dado de Teoría Crítica al nuevo movimiento cuyo centro lo constituirá el Instituto para la Investigación Social.

Para Horkheimer, sólo es entendible por Teoría Crítica: la aclaración racional de la realidad. Se hace perceptible la radical ruptura con las filosofías y teorías no sólo del Positivismo sino, a la par, del Historicismo a lo Dilthey o Simmel. Esto es, para los teóricos críticos -Horkheimer, Adorno, Benjamin, Marcuse- la crítica debe contener en su estructura un modelo de racionalidad dialéctica de inspiración hegeliano-marxiana, así como un sentido de la Historia en el que el progreso no sea producto de un mero desarrollo técnico, cuanto de un perfeccionamiento de la conciencia individual y social. El Marx de los "Manuscritos" es el referente oculto de los principios esenciales de la Escuela. Y ello se percibe de manera nítida en el sustrato de la gran mayoría de las obras de Horkheimer-Adorno.

Ahora bien, si el Marx de los "Manuscritos" reconduce el movimiento obrero hacia posiciones nuevas y diferentes, la necesidad de introducir a Freud imprimirá un giro nuevo al análisis sobre el capitalismo. En el libro sobre la "Psicología de Masas y análisis del Yo", Freud rebatía a los anteriores teóricos de la Psicología de las muchedumbres. Gustavo Le Play, Federico Le Bon, Williams McDougall o Gabriel Tarde pasaban a ser considerados defensores de un conservadurismo defensivo de índole psicológica, frente al advenimiento de unas nuevas formas de organización social que se imponían a la población en su conjunto. Para Freud, el Hombre-Masa significaba el triunfo del principio de Thanatos sobre el principio de Eros, la destrucción frente a la creatividad. La ansiedad afectiva de las poblaciones, sometidas y dominadas al sistema del poder de la máquina, finalizaba en la irracional necesidad de un líder que, cuan totém todopoderoso y cruel, "tranquilizase" las conciencias mutiladas, paradójicamente, por ese mismo líder. Víctimas y verdugos identificados en un mismo proyecto histórico. ¡Qué mayor malestar en la 
cultura que esa identificación con el agresor que las masas experimentarán en su conciencia, por efectos de la despiadada manipulación que el líder ejerce y sacraliza!, afirmarán los autores de la Teoría Crítica.

En efecto, sin Freud la reinterpretación de Marx que Horkheimer-Adorno llevarán a cabo, quedaría incompleta e insuficientemente precisa. Ese Hombre-Masa al que Ernst Toller había dramatizado y expuesto como la gran tragedia clásica del Siglo XX, pasa a ser, ahora, el protagonista colectivo de una nueva Teoría Social: la Sociofilosofía de la Escuela de Frankfurt. y con ello, el símbolo se hace concepto. De las emociones del teatro Expresionista se llega a las explicaciones freudomarxianas del pensamiento crítico. En este trayecto, el capitalismo ha mudado de piel. y aquella boa constrictora a la que Marx se refería en la viscosidad del nuevo sistema económico, había mudado de camisa. Del capitalismo industrial de los ludditas destructores de máquinas se había pasado a otra etapa del capitalismo, la del capitalismo post-industrial. Expresionismo, Dodecafonismo y Revolución convergían, final y lógicamente, en la Teoría Crítica.

Pero no sólo Toller y Berg subyacían en los análisis de la Escuela, también Kafka y Weber ponían el imprescindible matiz del ritualismo burocrático de la nueva sociedad. Samsa, el protagonista de "La Metamorfosis", exteriorizaba la condición ontológica y psíquica del Hombre-Masa. El hombre modificado en insecto. El poder de la máquina reemplazado por el dominio de lo nocivo y por la voracidad de un submundo inhumano que convierte en habitante de la colmena al individuo metamorfoseado en forma animal. La "jaula de hierro" weberiana era un peldaño más del calabozo de la conciencia. Pero ya no estamos en una prisión para fieras libres, sino que los individuos han sido colocados en una caja para cucarachas. Esa caja unidimensional será el sentido de la dialéctica crítica: salir de sus paredes, recobrando la forma y la esencia humanas.

El clima mental de los artistas, músicos, cineastas y teóricos de Weimar empujaba hacia un horizonte nuevo y diferente. Un espacio sin los límites de la dominación, ni de la explotación. Sin embargo, "el cine de sombras", el cine expresionista, alertaba de la cotidianidad de la locura y la alienación. Caligari y Nosferatu convivían con ese "ciudadano medio" que en el film " $M$ " de Lang es el auténtico vampiro que "estaba entre nosotros", como la película se subtitulaba casi proféticamente. Como estudió de un modo inigualable Sigfried Kracauer en su "De Caligari a Hitler", las masas alienadas y maquinizadas de "Metrópolis" se personificaban en "El último" de Murnau en la forma del prototipo psicológico de personalidad autoritaria que pocos años después predominaría en la sociedad de la década de los años treinta. Walter Benjamin señalará, desde su convicción crítica, que:

\footnotetext{
"Mientras más disminuye el significado social de un arte, más se
} 
separa la actitud crítica de la mera fruición por parte del público. Lo convencional se disfruta sin crítica alguna; lo que es verdaderamente nuevo se critica con repugnancia. En el cine, la actitud crítica y la del placer del público coinciden. Porque el hecho decisivo es el siguiente: en el cine más que en ningún otro lugar las reacciones individuales, cuya suma constituye la reacción de masa del público, está condicionada preliminarmente por su inmediata masificación. En cuanto, se manifiestan, se controlan." (BENJ AMIN, 1976, p. 25-26; 1988, p. 15-57.)

Tal control será el siniestro y obsesivo objetivo de las minorías asustadas ante el avance y aparición de una conciencia nueva de percibir y construir la realidad en las masas, y que tendrá en el Arte su manifestación más representativa. Del escenario teatral a la sala de cine y de la filosofía hegeliana a la teoría de Frankfurt, la percepción de una radical transformación de las conciencias está más allá del estrecho corsé político de la República de Weimar. Pero la corrupción había ido abriendo contrafuegos. Antes que las veredas revolucionarias recogiesen la herencia Espartaquista, el Nazismo empezó a asomar su perverso semblante. En vano Adorno y Horkheimer denunciarán el renacer de las supersticiones y de los miedos colectivos como formas de control social. En los "Estudios sobre autoridad y familia", Horkheimer avisa sobre la crueldad de lo atávico. Advertencia que Freud ya había observado en su premonitorio estudio sobre "Lo siniestro". Pero, ahora, lo siniestro revoloteaba sobre la multitud encaminándola hacia la catástrofe. El abismo al que se asoman los más conscientes creadores estará en la renuncia a la racionalidad, a la imaginación, al aura. La lucha entre racionalidad e irracionalidad nunca será tan faústica como la que durante las primeras décadas del Siglo XX se exteriorizan de una forma tan sobrecogedora. Y en ese combate, la Guerra Mundial acaba con vidas y esperanzas humanas. Pero, a la par, el conflicto bélico concluyó con el Siglo XX. Nuevas décadas quedaron después de mil novecientos cuarenta y cinco; y sin embargo, como en los Cuentos de Hadas, el tiempo y la Historia acabaron detenidos. Sin continuidad, ni persistencia. Artistas como náufragos, intelectuales sumergidos en la confusión. La ideología ocultó el pasado cultural en el que la resistencia ante la injusticia y la lucha contra la deshumanización fueron su cimiento. Ese enmascaramiento dura hasta nuestros días. Arte y Literatura fueron encaminándose hacia la transacción mercantil, Cine y Teatro devinieron en industria, pensadores y creadores se constituyeron en un circuito al servicio del perverso interés dominante. Como afirmaron Benjamin, Horkheimer y Adorno, en tal paralización de las mejores fuerzas intelectuales y creativas de la Humanidad, todos salimos perdiendo porque, en último término, nos fue arrebatada y arrancada el aura como la búsqueda y la esperanza, conjunta e histórica, de la anticipación consciente de la Utopía. 


\section{Referencias}

ADORNO, T. W. Dialéctica negativa. Madrid: Taurus, 1975.

BADÍ A, G. El espartaquismo. Barcelona: Noguer, 1971. (2 Vol.).

BENJ AMIN, W. El arte en la época de su reproductibilidad técnica. In: GODET, J. Los medios de la comunicación colectiva. México: Universidad Nacional Autónoma de México, 1976.

. Discursos interrumpidos. Madrid: Taurus, 1988.

$\bar{E} \bar{S} \bar{S} \overline{\mathrm{R}}$, L. H. La pantalla demoníaca. Madrid: Alianza, 1988.

FREUD, S. El malestar en la cultura. Madrid: Alianza, 1970.

El malestar en la cultura. In: Obras Completas. Madrid: Biblioteca Nueva, 1974. Volumen VIII, p. 3017-3068.

$\overline{1} \overline{9} \overline{6} \overline{.}$

. Psicología de masas y análisis del yo. Madrid: Alianza,

Psicología de masas y análisis del yo. In: Obras Completas.

Madrid: Biblioteca Nueva, 1974. v. 7, p. 2563-2611.

FRIEDERICH, W. P. Historia de la literatura alemana. Buenos Aires:

Sudamericana, 1973.

HARRIS, M. Teorías sobre la cultura en la era posmoderna. Barcelona: Crítica, 2000.

HEGEL, G. W. F. La razón en la Historia. Madrid: Seminarios y Ediciones, 1972.

HORKHEIMER, M. Estudios sobre autoridad y familia. Barcelona: Paidós, 2000.

Teoría tradicional y teoría crítica. Barcelona: Paidós, 2002.

KLEI N, C. De los espartaquistas al Nazismo. La república de Weimar. Barcelona: Península, 1970.

KRACAUER, S. De Caligari a Hitler. Historia psicológica del cine alemán. Barcelona: Paidós, 1985.

LE BON, G. Psicología de las masas. Madrid: Morata, 1987.

LUKÁCS, G. Historia y conciencia de clase. Barcelona: Grijalbo, 1978. LUXEMBURGO, R. La acumulación del capital. México: Grijalbo, 1967. La liga Spartakus. Barcelona: Anagrama, 1976.

MARX, K. Manuscritos de Economía y Filosofía. Madrid: Alianza, 1974.

. Contribución a la crítica de la Economía Política. Madrid: Älberto Corazón, 1970.

MODERN, R. E. La literatura alemana. México: Fondo de Cultura Económica, 1961.

MUÑOZ, B. Dodecafonismo y sociedad de entreguerras. El reflejo del conflicto social en el 'Wozzeck' de Alban Berg. Revista Española de Investigaciones Sociológicas, v. 84, n. 1, p. 259-275, OctubreDiciembre, 1998.

RAMOS OLIVEI RA, A. Historia social y política de Alemania. México: F. C. E., 1964. (2 Vol.).

RICHARD, L. Del expresionismo al nazismo. Barcelona: Gustavo Gili, 1979. 
SCHNEIDER, H. Épocas de la literatura alemana. Buenos Aires: Nova, 1956.

SCHOPENHAUER, A. El mundo como voluntad y representación. Buenos Aires, Biblioteca Nueva, 1942.

TOLLER, E. El Hombre-Masa, y Los destructores de máquinas. Barcelona: Alikornio, 2002.

ZEITLIN, M. I deología y teoría sociológica. Madrid: Amorrortu, 1987.

\section{Endereço para correspondência :}

Blanca Muñoz

Universidad Carlos III de Madrid, C/. Madrid, 126, 28903 Getafe, Madrid, Espanha

Endereço eletrônico: bmunoz@polsoc.uc3m.es

Recebido em: 20/03/2010

Aceito para publicação em: 24/04/2010

Acompanhamento do processo editorial: Ariane P. Ewald e Jorge Coelho Soares

\section{Notas}

${ }^{1}$ En esta obra se destacan los temas centrales que hacen de la Literatura Alemana un modelo del desarrollo de las épocas históricas por sus ideales literarios-filosóficos.

${ }^{2}$ Kracauer merecería un homenaje y reconocimiento por su importancia no sólo en su aplicación de Freud al análisis del Cine Expresionista, sino asimismo por su influencia determinante en la Primera Generación de la Escuela de Frankfurt.

${ }^{3}$ La figura de Lulu presentada en el film La caja de Pandora de Pabst simbólicamente podría interpretarse como una metáfora de la República de Weimar, incluso su sórdida muerte a manos de Jack El Destripador puede entenderse como una referencia indirecta a la llegada del Nazismo. 